\title{
SISTEM INFORMASI TRANSAKSI KEUANGAN PADA PT AULIA PRIMA ALAMI DEPOK
}

\author{
Khairiyyah Putri ${ }^{1}$, Ibnu Rusdi ${ }^{2}$, Ade Sri Mulyani ${ }^{3}$ \\ ${ }^{1}$ AMIK BSI Jakarta \\ e-mail: khairiyyahputri@yahoo.com \\ 2STMIK Nusa Mandiri Jakarta \\ e-mail: irusyd19@gmail.com \\ ${ }^{3} \mathrm{AMIK}$ BSI Jakarta \\ e-mail: ade.aml@bsi.ac.id
}

\begin{abstract}
Abstrak
Teknologi komputer telah banyak membantu perusahaan dalam menjalankan kegiatan bisnis, dalam hal ini akuntansi sangat berperan penting bagi perusahaan sebagai penunjang kegiatan. Dengan didukung teknologi komputer, pencatatan transaksi bisnis yang sebelumnya menggunakan buku dan memerlukan tempat pengarsipan dapat diganti dengan teknologi komputer. Penggunaan aplikasi komputer akuntansi sangatlah efektif dan efisien bagi seorang pengusaha dalam menjalankan bisnisnya. PT Aulia Prima Alami adalah perusahaan dagang yang bergerak dalam bidang penjualan berbagai macam jenis gula dan jahe. Sistem pencatatan data transaksi keuangan pada PT Aulia Prima Alami masih belum menerapkan sistem yang terkomputerisasi, sehingga dalam pembuatan laporan menjadi terhambat. Adanya perkembangan teknologi untuk pencatatan transaksi keuangan dengan terciptanya software MYOB Premier V16 sangat membantu perusahaan dalam pengolahan data transaksi keuangan. Hasil dari penerapan memperlihatkan bahwa aplikasi MYOB Premier dapat berjalan dengan baik dan dapat mengatasi permasalahan penjualan, pembelian, pencatatan uang masuk, pencatatan uang keluar dan pembuatan laporan keuanganyang ada pada PT Aulia Prima Alami.
\end{abstract}

Kata Kunci: Sistem Informasi, Transaksi, Keuangan, PT Aulia Prima Alami

\begin{abstract}
Computer technology has been helped the companies in running the bussiness, in this case accounting is very important for the companiesas the activity support. By the support from computer technology, the record of bussiness transaction which using the book before and need to be archieved can be replaced with computer technology. The use of computer accounting application is very effective and efficience for an entrepreneurin running their bussiness. PT Aulia Prima Alami is a trade company which handle in selling variants of sugar and ginger. The financial data recording system in PT Aulia Prima Alami still not applying the computerization system, which obstracting the report. The exsitance technology development for recording the financial transaction with innovation from the latest software MYOB Premier $V 16$ is very helpful for the company in developing the financial data. The result of this apply shows that MYOB Premier application can running well and also can resolve the problems of selling, buying, the recording of input fund, ouput fund and the making of financial report in PT Aulia Prima Alami.
\end{abstract}

Keywords: Information Systems, Transactions, Finance, PT Aulia Prima Alami

\section{Pendahuluan}

Teknologi komputer telah banyak membantu perusahaan dalam menjalankan kegiatan bisnis, dalam hal ini akuntansi sangat berperan penting bagi perusahaan sebagai penunjang kegiatan. Dengan didukung teknologi komputer, pencatatan transaksi bisnis yang sebelumnya menggunakan buku dan memerlukan tempat pengarsipan dapat diganti dengan teknologi komputer.

Sistem informasi akuntansi di dalam perusahaan akan menghasilkan 
laporan keuangan. Informasi yang dihasilkan dari proses akuntansi tersebut harus dapat menjawab kebutuhan umum para pemakainya (Rahmawati, 2015).

Saat ini terdapat beberapa software program aplikasi akuntansi yang dapat digunakan untuk mempermudah pengguna dalam mengerjakan laporan akuntansi pada suatu perusahaan diantaranya yaitu Myob Accounting, Zahir Accounting, Accurate dan lain sebagainya (Normah, 2018)

PT Aulia Prima Alami merupakan perusahaan dagang yang kegiatan usahanya menjual gula dan jahe. Dimana sistem pengolahan data akuntansi masih bersifat manual, yaitu menggunakan kertas sebagai media pencatatan penjualan dan pembelian. Didalam perusahaan ini masih terdapat rangkap jabatan karena belum adanya karyawan yang dapat dipercaya dan kompeten yang dapat mempertanggungjawabkan keuangan secara bener sehingga dalam pembuatan laporan keuangan menjadi terhambat. Dengan sistem yang berjalan saat ini, laporan keuangaan yang dihasilkan dan penyimpanan dokumen yang terlalu banyak menyebabkan pencarian data lebih sulit terlebih jika dokumen hilang akan mengakibatkan terganggunya proses akuntansi.

\section{Metode Penelitian}

\subsection{Metode Pengumpulan Data}

Penulis melakukan pengumpulan data dengan metode sebagai berikut :

\section{Metode Pengamatan (Observasi)}

Dalam hal ini penulis mengumpulkan dan memperoleh data melalui observasi pada PT Aulia Prima Alami secara langsung terhadap kegiatan yang berhubungan dengan masalah yang diambil. Hasil dari pengamatan tersebut langsung dicatat oleh penulis dan dari kegiatan observasi dapat diketahui kesalahan atau proses dari kegiatan tersebut.

2. Metode Wawancara

Dalam metode wawancara ini, wawancara dilakukan dengan pemilik PT Aulia Prima Alami guna mendapatkan data yang akurat.

3. Metode Studi Pustaka

Melakukan pengumpulan teori-teori yang dibutuhkan bersumber dari buku-buku, literatur, jurnal, data- data perusahaan serta bacaan lain yang berkaitan dengan masalah.

\subsection{Metode Pengembangan Software}

Menurut (Rosa, Shalahuddin, 2011)

"Software Development Life Cycle atau sering disebut dengan System Development Lyfe Cycle adalah proses mengembangkan atau mengubah suatu sistem perangkat lunak dengan menggunakan model-model atau metodologi yang digunakan orang untuk mengembangkan sistem-sistem perangkat lunak sebelumnya (berdasarkan best practice atau cara-cara yang sudah teruji baik)".

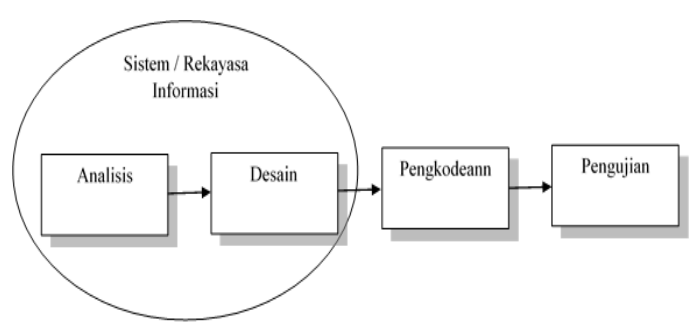

Gambar 1. Model Waterfall

Sumber : Rosa, Shalahuddin (2016)

1. Analisis Kebutuhan

Menganalisis kebutuham pemakai sistem perangkat lunak dan mengembangkan user. Membuat dokumen kebutuhan fungsional.

2. Desain (Design)

Mentransformasikan kebutuhan detail menjadi kebutuhan yang sudah lengkap, dokumen desain sistem focus pada bagaimana dapat memenuhi fungsi yang dibutuhkan.

3. Pengembangan (Development)

Mengonversi desain ke sistem informasi yang lengkap termasuk bagaimana memperoleh dan melakukan instalasi lingkungan sistem yang dibutuhkan; membuat basis data dan mempersiapkan prosedur file pengujian, pengodean, pengompilasian, memperbaiki dan membersihkan program; peninjauan pengujian.

4. Integrasi dan pengujian (Integration and test)

Mendemonstrasikan sistem perangkat lunak bahwa telah memenuhi kebutuhan yang dispesifikasikan pada dokumen kebutuhan fungsional. 
Dengan diarahkan oleh staf penjamin kualitas dan user. Menghasilkan laporan analisis pengujian.

5. Implementasi (Implementation)

Termasuk pada persiapan implementasi, implementasi perangkat lunak pada lingkungan produksi dan menjalankan resolusi dari permasalahan yang teridentifikasi dari fase integrasi dan pengujian.

\subsection{Pengertian Sistem Informasi Akuntansi}

Menurut Steven A. Moscove dalam (Zamzami, Nusa, \& Faiz, 2016) "Sistem informasi akuntansi adalah komponen organisasi yang mengumpulkan, menggolongkan mengolah, menganalisis, dan mengkomunikasikan informasi keuangan yang relevan".

Menurut (Krismiaji, 2015) "Sistem informasi akuntansi adalah sebuah sistem yang memproses data dan berguna menghasilkan informasi yang bermanfaat untuk merencanakan, mengendalikan dan mengoperasikan bisnis."

Untuk dapat menghasilkan informasi yang diperlukan dalam pembuat keputusan, sistem informasi harus melaksanakan tugas-tugas sebagai berikut

1. Mengumpulkan transaksi dan data lain dan memasukannya ke dalam sistem.

2. Memproses data transaksi

3. Menyimpan data untuk keperluan dimasa mendatang

4. Menghasilkan informasi yang diperlukan dengan memproduksi laporan, atau memungkinkan para pemakai untuk melihat sendiri data yang tersimpan dikomputer

5. Mengendalikan seluruh proses sedemikian rupa sehingga informasi yang dihasilkan akurat dan dapat dipercaya

6. Dari pendapat para ahli diatas dapat disimpulkan bahwa sistem informasi akuntansi adalah kumpulan sumber daya seperti manusia dan komponen lain, yang diatur untuk mengubah data menjadi informasi akuntansi yang dapat dikomunikasikan ke pengguna untuk pengambilan keputusan.

\subsection{Pengertian Jurnal}

Menurut (Shatu, 2016) Jurnal yaitu transaksi-transaksi keuangan suatu badan usaha yang dicatat berdasarkan dokumen- dokumen pembukuan yang bertujuan untuk pendataan. Jurnal dikenal juga sebagai buku pemasukan utama karena menjadi tempat terjadinya pencatatan transaksi pertama atau penyesuaian pemasukan transaksi-transaksi.

Menurut (Eddy, 2010) "Sewamenyewa adalah suatu persetujuan dengan mana pihak yang satu mengikatkan dirinya untuk memberikan kenikmatan suatu barang dengan pihak yang lain selama waktu tertentu, dengan pembayaran suatu harga yang disanggupi oleh pihak terakhir".

Pada semua transaksi penyewaan yang terjadi akan masuk ke dalam jurnal penerimaan kas. Sedangkan jurnal penerimaan kas menurut (Astuty, 2015) adalah "Jurnal yang digunakan untuk mencatat transaksi yang berkaitan dengan penerimaan kas baik berupa uang, cek ataupun bilyet giro. Transaksi yang berkaitan dengan jurnal ini antara lain: penerimaan dari pelunasan atau pembayaran piutang, penjualan barang dagangan secara tunai dan penerimaan pendapatan lain-lain". penyewaan :

Contoh proses jurnal transaksi

\section{Pada saat terjadi penyewaan}

$$
\begin{aligned}
& \text { Piutang Usaha } \quad x x x \\
& \text { Pendapatan Jasa } \quad \text { xxx }
\end{aligned}
$$

2. Pada saat pembayaran

$$
\begin{aligned}
& \text { Kas } \\
& \text { Piutang Usaha }
\end{aligned}
$$

\section{Hasil dan Pembahasan}

Permasalahan saat ini adalah, meskipun perusahaan sudah berkembang pesat dalam kegiatan bisnisnya, namun perkembangan tersebut tidak dikuti dengan kemampuan pengelolalan manajemen yang baik, salah satunya pada proses pencatatan akuntansi. Proses pencatatan akuntansi pada perusahaan ini dapat dikatakan belum cukup baik karena kurangnya sumber daya manusia yang mampu memahami sistem pencatatan akuntansi dalam perusahaan ini.

Dalam tugas akhir ini penulis melakukan penelitian terhadap sistem kerja perusahaan ini, dan mencoba mengaplikasikan sebuah sofware akuntansi MYOB Premier V16 kedalam sistem kerja pencatatan akuntansi yang masih dilakukan 
secara manual untuk mempermudah sistem kerja dalam pengelolah data akuntansi dan mempercepat laju informasi yang dibutuhkan. Pengolahan Data pada Software MYOB Premier V16.

1. Setup Awal Data Persahaan

Langkah pertama yang harus dilakukan adalah pembuatan databse perusahaan perusahaan yang baru, yaitu dengan langkah menginput informasi perusahaan, dilanjutkan dengan pemilihan periode akuntansi, konfirmasi kebenaran data yang telah diinput, dilanjutkan dengan pemelihan dalam pembuatan daftar akun akun, dan d iakhiri dengan pemilihan tempat penyimpanan data perusahaan.

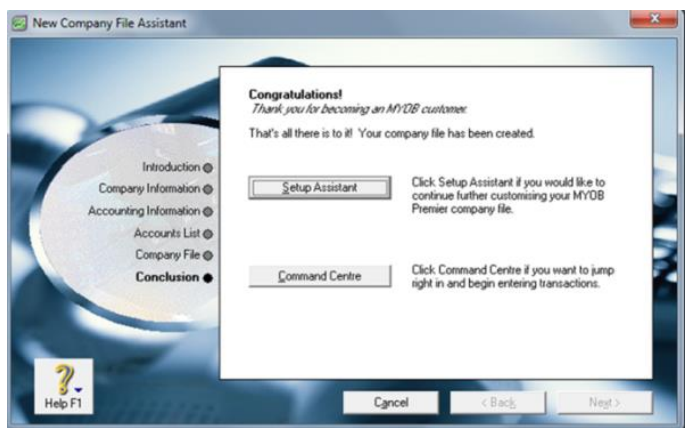

Gambar 2. Pembuatan Database Perusahan Baru

Sumber: Hasil Pengolahan Data (2018)

2. Input Salda Awal Akun

Tabel 1. Neraca Saldo Periode

Sebelumnya (dalam Rupiah)

\begin{tabular}{|c|l|r|l|}
\hline $\begin{array}{r}\text { Kode } \\
\text { Akun }\end{array}$ & Nama Akun & \multicolumn{1}{c|}{ Debet } & Kredit \\
\hline $1-1100$ & Kas & 1.300 .000 & \\
\hline $1-1200$ & Bank Mandiri & 16.382 .500 & \\
\hline $1-1300$ & Bank BCA & 17.168 .300 & \\
\hline $1-1400$ & $\begin{array}{l}\text { Piutang } \\
\text { Dagang }\end{array}$ & 8.964 .700 & \\
\hline $1-1500$ & Dibayar & & \\
& Dimuka & 8.000 .000 & \\
\hline $1-1600$ & Perlengkapan & 500.000 & \\
\hline $1-1700$ & Persediaan & 55.631 .250 & \\
\hline
\end{tabular}

\begin{tabular}{|c|l|r|l|}
\hline & $\begin{array}{l}\text { Barang } \\
\text { Dagang }\end{array}$ & & \\
\hline $1-1900$ & Peralatan & 5.500 .000 & \\
\hline $3-1000$ & Modal & & 113.446 .750 \\
\hline Jumlah & & 113.446 .750 & 113.446 .750 \\
\hline
\end{tabular}

Sumber: Hasil Penelitian (2018)

Tabel 1. Adalah saldo awal bulan Maret 2018. Untuk menginput membuat kode customer, pilih menu bar Setup, pilih Balance, pilih Account Opening Balanc. Kemudian isikan Saldo Awal Akun tersebut seperti gambar dibawah ini dan pastikan amount left to be allocated Rp 0 , jika proses penginputan saldo awal akun sudah selesai klik OK.

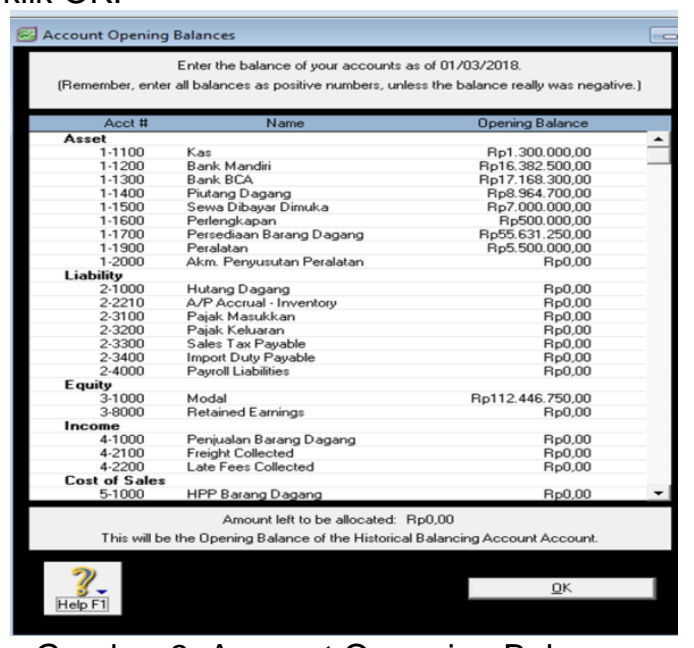

Gambar 3. Account Oppening Balances Sumber: Hasil Pengolahan Data (2018)

3. Input Saldo Awal Piutang

Tabel 2. Saldo Awal Piutang

\begin{tabular}{|l|l|c|}
\hline \multicolumn{1}{|c|}{ Customer } & \multicolumn{1}{|c|}{$\begin{array}{c}\text { Saldo } \\
\text { Piutang }\end{array}$} & Invoice \\
\hline Bu Ely & $\mathrm{Rp} \mathrm{316.000}$ & INV-01 \\
\hline Pujasari Bojong Gede & $\begin{array}{l}\mathrm{Rp} \\
1.228 .700\end{array}$ & INV-02 \\
\hline Aneka Buana & $\mathrm{Rp}$ & INV-03 \\
Cirendem & 1.075 .000 & \\
\hline Aneka Buana Pondok & $\mathrm{Rp}$ & INV-04 \\
Labu & 1.003 .000 & \\
\hline Bu Dian & $\mathrm{Rp} \mathrm{700.000}$ & INV-05 \\
\hline Fortuna Swalayan & $\mathrm{Rp}$ & INV-06 \\
\hline
\end{tabular}




\begin{tabular}{|l|l|l|}
\hline & 3.204 .000 & \\
\hline Gubug Mang Engking & $\mathrm{Rp}$ & INV-07 \\
& 1.438 .000 & \\
\hline Total & $\mathrm{Rp}$ & \\
& 8.964 .700 & \\
\hline
\end{tabular}

Sumber: Hasil Penelitian (2018)

Tabel 2. Menunjukan data saldo awal piutang pada awal bulan Maret 2018 . Langkah penginputan adalah mulai dari membuat data customer dengan memilih modul Card File, pilih customer, pilih New, lalu Record. Menginput saldo awal piutang, pilih menu bar Setup, pilih Balances, Pilih Customer Balances. Pilih Customer kemudiaan klik Add Sale. Kemudian isi saldo awal piutang. Setelah selesai klik Record.

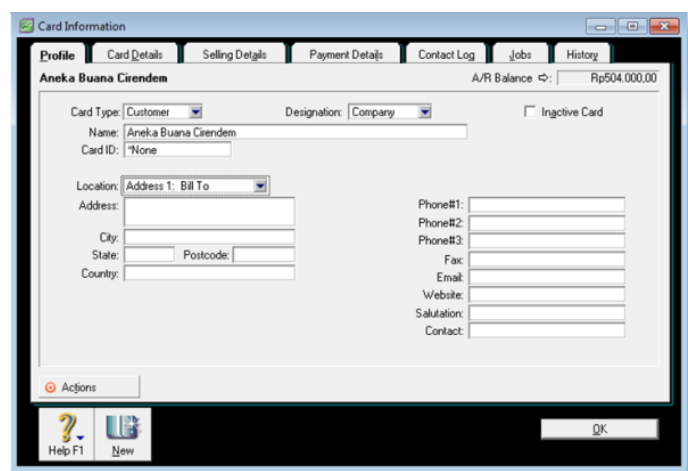

Gambar 4. Tampilan Card Information Sumber: Hasil Pengolahan Data (2018)

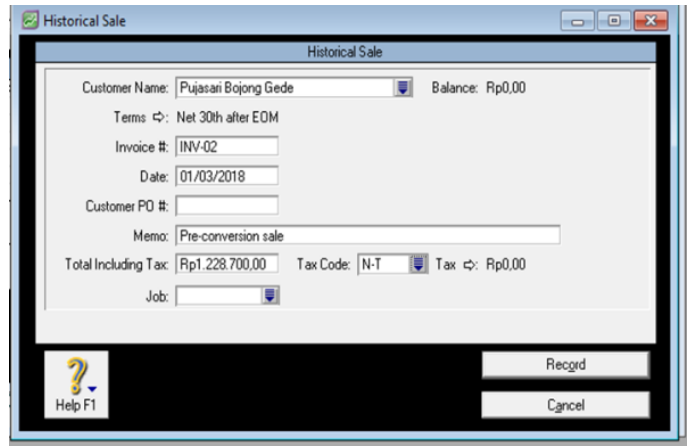

Gambar 5. Input Saldo Awal Piutang Sumber: Hasil Pengolahan Data (2018)

4. Input Data Barang

Tabel 3. Daftar persediaan Barang

\begin{tabular}{|c|c|c|c|}
\hline $\begin{array}{c}\text { Kode } \\
\text { Barang }\end{array}$ & $\begin{array}{c}\text { Nama } \\
\text { Barang }\end{array}$ & $\begin{array}{l}\text { Jumlah } \\
\text { Barang }\end{array}$ & Satuan \\
\hline GA450 & $\begin{array}{l}\text { Gula Aren } \\
450 \mathrm{gr}\end{array}$ & 1600 & Pcs \\
\hline
\end{tabular}

\begin{tabular}{|c|l|r|c|}
\hline GA250 & $\begin{array}{l}\text { Gula Aren } \\
\text { 250gr }\end{array}$ & 1200 & Pcs \\
\hline GK450 & $\begin{array}{l}\text { Gula } \\
\text { Kelapa } \\
450 \mathrm{gr}\end{array}$ & 1000 & Pcs \\
\hline GK250 & $\begin{array}{l}\text { Gula } \\
\text { Kelapa } \\
\text { 450gr }\end{array}$ & 960 & Pcs \\
\hline JM & $\begin{array}{l}\text { Jahe } \\
\text { Merah }\end{array}$ & 380 & $\mathrm{Kg}$ \\
\hline GAS & $\begin{array}{l}\text { Gula Aren } \\
\text { Semut }\end{array}$ & 220 & $\mathrm{Kg}$ \\
\hline JS & $\begin{array}{l}\text { Jahe Serai } \\
\text { Jahe } \\
\text { Habbat }\end{array}$ & 25 & Botol \\
\hline JMO & $\begin{array}{l}\text { Jahe } \\
\text { Merah Ori }\end{array}$ & 28 & Botol \\
\hline GSO & $\begin{array}{l}\text { Gula } \\
\text { Semut Ori }\end{array}$ & 10 & Botol \\
\hline
\end{tabular}

Sumber: Hasil Penelitian (2018)

Tabel 3. Adalah daftar persediaan pada PT Aulia Prima Alami pada awal bulan Maret 2018. Untuk membuat kode barang pilih modul inventory, pilih Item List, pilih New. Kemudian input data persediaan, jika penginputan telah selesai Klik OK.

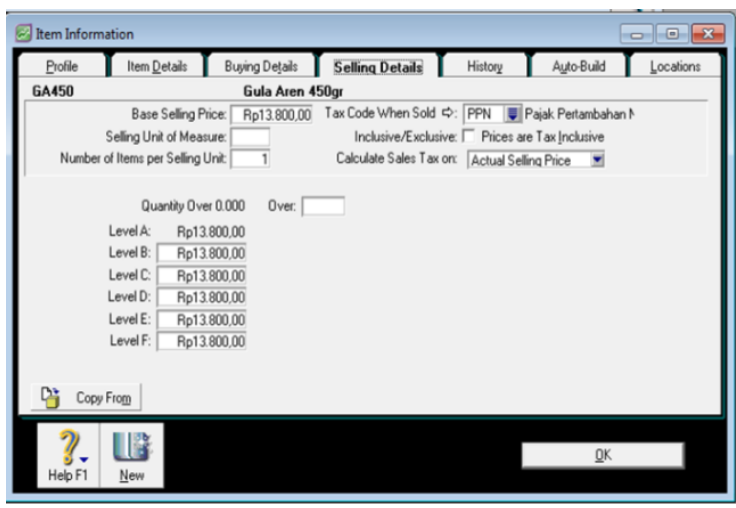

Gambar 6. Langkah Input Data Persediaan Sumber: Hasil Pengolahan Data (2018)

5. Input Saldo Awal Persediaan (Inventory)

Untuk menginput saldo awal Inventory, pilih modul Inventory, pilih Count Inventory, kemudian isi jumlah kuantitas setiap barang pada kolom counted, klik Adjust Inventory, klik continue, klik Opening Balance, selanjutnya isi harga pokok barang per unit di kolom unit cost, beserta akun persediaan pada kolom account. Setelah selesai klik Record. 
Tabel 4. Saldo Awal Persediaan (Inventory)

\begin{tabular}{|c|c|c|c|c|c|c|}
\hline Kode & Nama Barang & Jumlah & Satuan & HPP & Harga Jual & Total \\
\hline GA450 & Gula Aren 450gr & 1600 & Pcs & Rp 9.750 & Rp 13.800 & Rp 15.600 .000 \\
\hline GA250 & Gula Aren 250gr & 1200 & Pcs & $\operatorname{Rp} 5.500$ & Rp 9.300 & Rp 6.600 .000 \\
\hline GK450 & Gula Kelapa 450gr & 1000 & Pcs & Rp 8.650 & Rp 12.800 & Rp 8.650.000 \\
\hline GK250 & Gula Kelapa 250gr & 960 & Pcs & $\operatorname{Rp} 4.950$ & Rp 8.400 & Rp 4.752.000 \\
\hline JM & Jahe Merah & 380 & $\mathrm{Kg}$ & $\begin{array}{c}\text { Rp. } \\
35.500\end{array}$ & Rp 54.500 & Rp 13.490.000 \\
\hline GAS & Gula Aren Semut & 220 & $\mathrm{Kg}$ & $\operatorname{Rp} 25.000$ & Rp 47.000 & Rp 5.500.000 \\
\hline JS & Jahe Serai & 25 & Botol & Rp 13.750 & Rp 29.000 & Rp 343.750 \\
\hline $\mathrm{JH}$ & Jahe Habbat & 15 & Botol & Rp 13.750 & Rp 29.000 & Rp 206.250 \\
\hline JMO & Jahe Merah Ori & 28 & Botol & $\operatorname{Rp} 12.875$ & Rp 29.000 & $\operatorname{Rp} 360.500$ \\
\hline GSO & Gula Semut Ori & 10 & Botol & Rp 12.875 & Rp 29.000 & Rp 128.750 \\
\hline \multicolumn{6}{|c|}{ Jumlah Total Persediaan } & $\operatorname{Rp} 55.631 .250$ \\
\hline
\end{tabular}

Sumber: Hasil penelitian (2018)

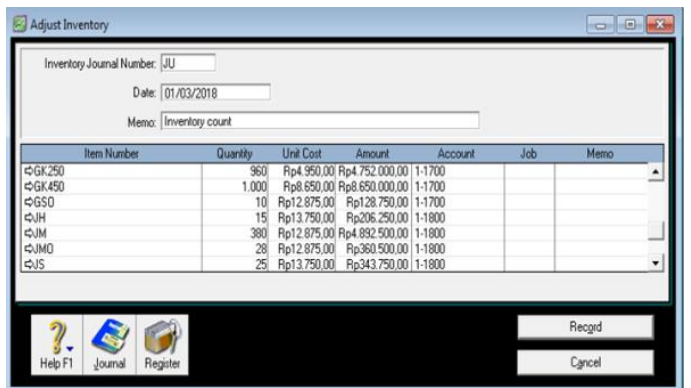

Gambar 7. Input Saldo Awal Persediaan (Inventory)

Sumber: Hasil Pengolahan Data (2018)

6. Input Data Transaksi

Tabel 5. Transaksi Pengeluaran Kas

\begin{tabular}{|c|l|}
\hline & \\
Tanggal & Membayar Biaya Oprasional sebesar Rp \\
05/03/2018 & 20.000 dengan bukti transaksi KK- \\
& $02 / 0503$
\end{tabular}

Sumber: Hasil Penelitian (2018)

Pilih Modul Account, Pilih Record Journal Entry, kemudian input data transaksi, klik Record.

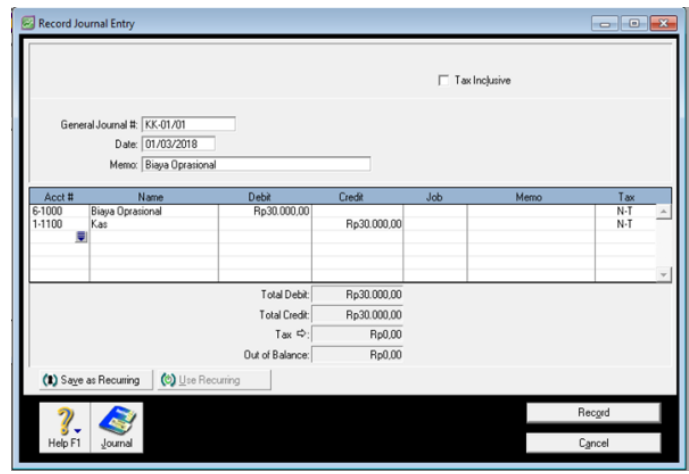

Gambar 8. Pencatatan Pengeluan Kas Sumber: Hasil Pengolahan Data (2018)

Tabel 6. Pembayaran Piutang dari Customer

\begin{tabular}{|c|l|}
\hline & \multicolumn{2}{|l|}{ Menerima pembayaran piutang dari Bu } \\
Tanggal & Ely, dengan invoice jvs/03/015.ely \\
$23 / 03 / 2018$ & sebesar Rp 316.000 dengan bukti \\
& transaksi Nomor KM-1203 (Transfer \\
& Bank Mandiri)
\end{tabular}

Sumber: Hasil Penelitian (2018)

Pilih modul Sales, pilih Receive Payments, pilih customer Bu Ely, input data transaksi, setelah selesai klik OK. 


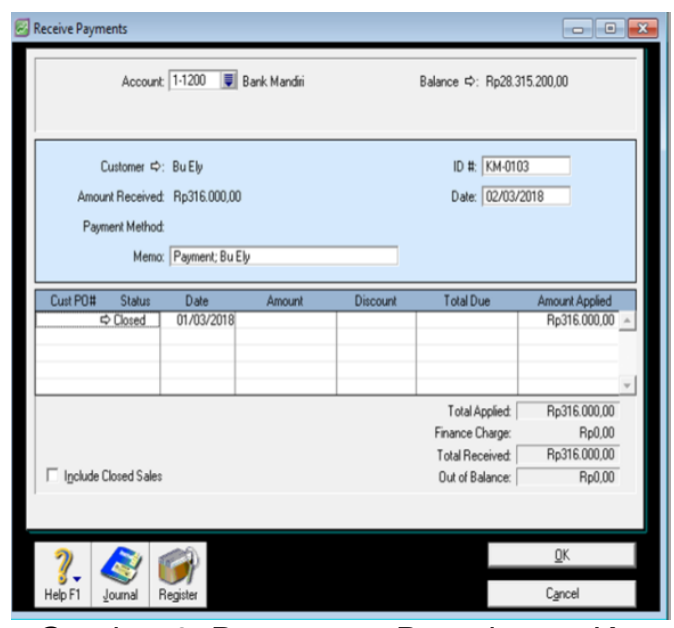

Gambar 9. Pencatatan Penerimaan Kas Sumber: Hasil Pengolahan Data (2018)

Tabel 7. Penjualan Secara Kredit

\begin{tabular}{|c|l|l|l|l|}
\hline \multicolumn{5}{|c|}{ Dijual dengan kredit kepada Pujasari, dengan rincian } \\
\hline \multirow{2}{*}{$\begin{array}{c}\text { Tanggal } \\
\text { 06/03/2018 }\end{array}$} & $\begin{array}{l}\text { Nama } \\
\text { Barang }\end{array}$ & Qty & $\begin{array}{l}\text { Harga } \\
\text { Satuan }\end{array}$ & $\begin{array}{l}\text { Jumlah } \\
\text { Harga }\end{array}$ \\
\cline { 2 - 5 } & $\begin{array}{l}\text { Kelapa } \\
\text { 450gr }\end{array}$ & 40 & 12.600 & 504.000 \\
\hline $\begin{array}{c}\text { No. Inv } \\
\text { jvs- } \\
\text { 03/012/ps }\end{array}$ & Total & 504.000 \\
\hline
\end{tabular}

Sumber: Hasil Penelitian (2018)

Pilih Modul Sales, pilih Enter Sales, pilih customer Pujasari, selanjutnya input data transaksi, kemudian Klik Record.

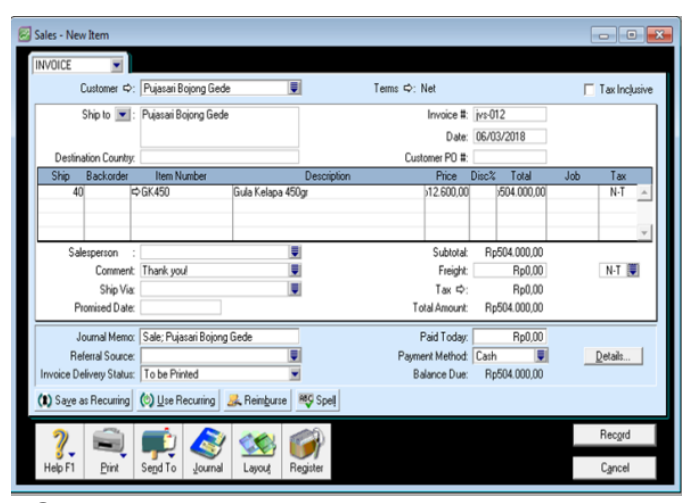

Gambar 10. Pencatatan Penjualan Kredit

Sumber: Hasil Pengolahan Data (2018)
Tabel 8. Pembelian Barang Secara Kredit

\begin{tabular}{|c|l|l|l|l|}
\hline \multicolumn{5}{|c|}{ Dibeli dengan kredit dari Berkah Madani, dengan } \\
rincian sebagai berikut: \\
\hline \multirow{2}{*}{$\begin{array}{c}\text { Tanggal } \\
21 / 03 / 2018\end{array}$} & $\begin{array}{l}\text { Nama } \\
\text { Barang }\end{array}$ & Qty & $\begin{array}{l}\text { Harga } \\
\text { Satuan }\end{array}$ & $\begin{array}{l}\text { Jumlah } \\
\text { Harga }\end{array}$ \\
\cline { 2 - 5 } & $\begin{array}{l}\text { Jahe } \\
\text { Serai }\end{array}$ & 40 & 13.500 & 540.000 \\
& $\begin{array}{l}\text { Jahe } \\
\text { Habbat }\end{array}$ & 60 & 12.000 & 720.000 \\
\hline & $\begin{array}{l}\text { Gula } \\
\text { Kelapa } \\
\text { 450gr }\end{array}$ & 900 & 8.650 & 7.785 .000 \\
\hline $\begin{array}{c}\text { Biaya } \\
\text { Angkut }\end{array}$ & & & 520.000 \\
\hline KK-02/2103 & \multicolumn{4}{|l}{ Total } \\
Sumber: Hasil Penelitian $(2018)$ & 9.565 .000 \\
\hline
\end{tabular}

Pilih Modul Purchase, pilih Enter Purchase, kemudian isi data transaksi, kemudian klik Record.

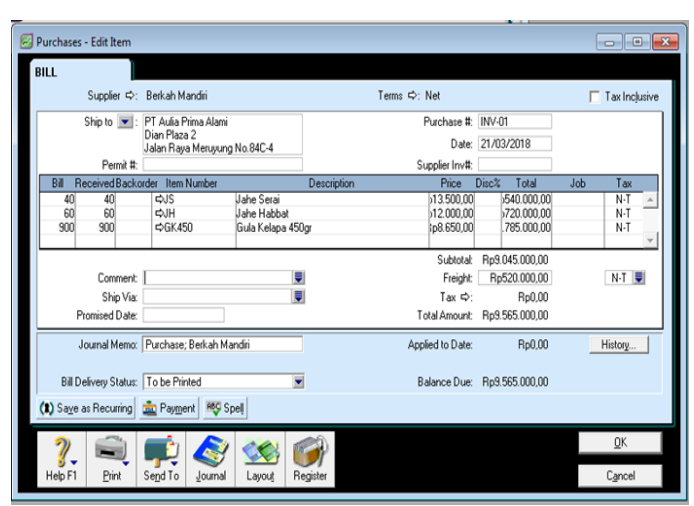

Gambar 11. Pencatatan Pembelian Secara Kredit.

Sumber: Hasil Pengolahan Data (2018)

7. Laporan

a. Laporan Laba Rugi

Pilih Reports, pilih Accounts, pilih Profit \& Loss (Accural) $\rightarrow$ Klik Disply. 


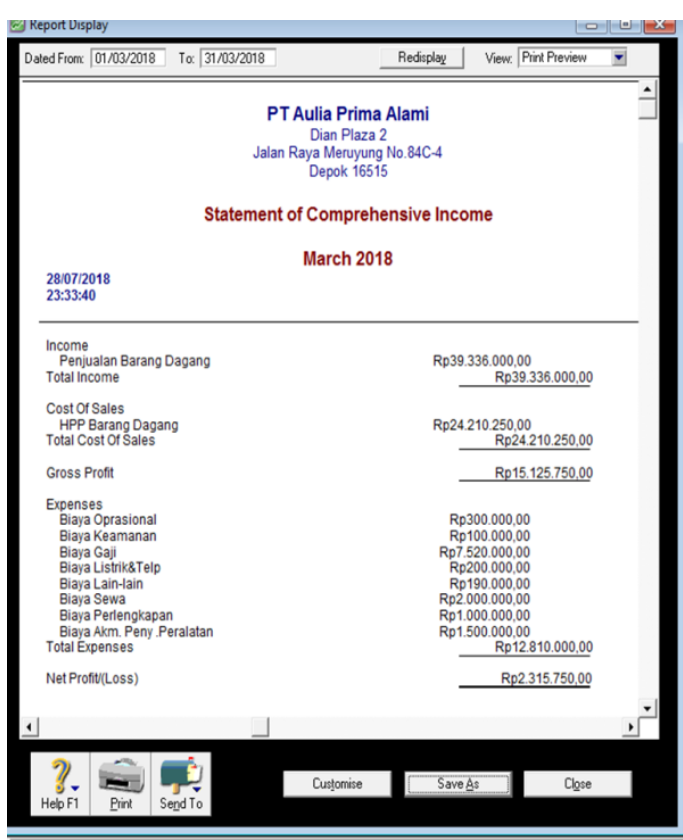

Gambar 12. Laporan Laba/Rugi Sumber: Hasil Pengolahan Data (2018)

b. Laporan Neraca Pilih Reports, Pilih Accounts, Pilih Standard Trial Balance.

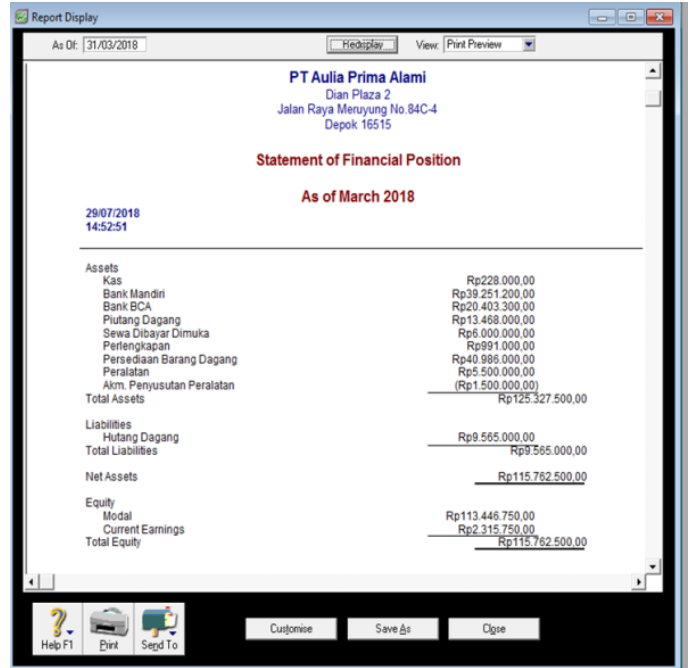

Gambar 13. Laporan Neraca Sumber: Hasil Pengolahan Data (2018)

c. Laporan Arus Kas Pilih Reports, pilih Banking, pilih Statement of Cash Flow.

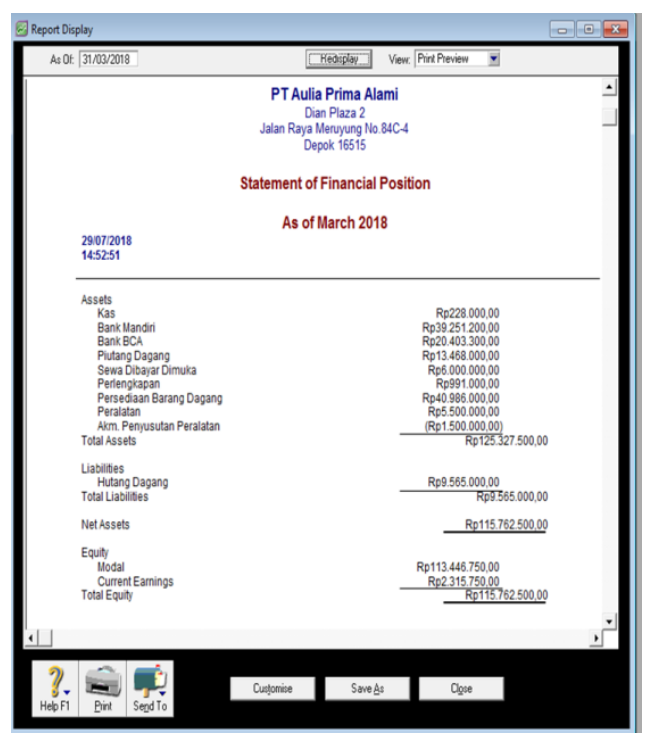

Gambar 14. Laporan Arus Kas Sumber: Hasil Pengolahan Data (2018)

8. Analisa Laporan Keuangan

Dari hasil laporan laba rugi dan laporan neraca diatas dapat dianalisa laporan keuangan sebagai berikut:

a. Rasio Rentabilitas

Margin Laba Kotor

$=\frac{\text { Laba Kotor }}{\text { Penjualan Bersih }} \times 100 \%$

$=\frac{\text { Rp. } 15 \cdot 125.750}{\text { Rp. } 39 \cdot 336.000} \times 100 \%$

$=0.384$

$=38.4 \%$

Artinya kemampuan perusahaan dalam menghasilkan laba kotor dari penjualan bersih adalah sebesar $38,4 \%$.

b. Rasio Likuiditas

1). Current Ratio

Current Ratio

$=\frac{\text { Aktiva Lancar }}{\text { Hutang Lancar }} \times 100 \%$

$=\frac{\text { Rp. } 121.327 .500}{\text { Rp. 9.565.000 }} \times 100 \%$

$=12.684$ 
$=1268.4 \%$

Artinya setiap 1 rupiah hutang

jangka pendek perusahaan dijamin

pembayaran dengan $\operatorname{Rp} 12,684$

aset perusahaan.

2). Quick Ratio

Quick Ratio

$=\frac{\text { Aktiva Lancar }- \text { Persediaan }}{\text { Hutang Lancar }} \times 100 \%$

$$
\begin{gathered}
=\frac{\text { Rp. } 121.327 .500-40.986 .000}{\text { Rp. } 9.565 .000} \times 100 \% \\
=8.399 \\
=839.9 \%
\end{gathered}
$$

Artinya Kemampuan perusahaan memenuhi hutang lancar dengan aktiva perusahaan adalah setiap Rp 1 hutang lancar dijamin dengan Rp 839,9 aktiva lancar yang likuid atau dalam bentuk uang bukan persediaan barang dagang.

3). Cash Ratio

Cash Ratio $=\frac{\text { Kas }(\text { Bank })}{\text { Hutang Lancar }} \times 100 \%$

$=\frac{\text { Rp. } 59 \cdot 882.500}{\text { Rp. } 9.565 .000} \times 100 \%$

$=6.260$

$=626.0 \%$

Artinya setiap Rp 1 hutang lancar

dapat dijamin oleh $\mathrm{Rp} \quad 6,260$

Kas(Bank).

c. Rasio Solvabilitas

1). Debt to Capital Asset

Debt to Capital Asset

$=\frac{\text { Total Hutang }}{\text { Total Aset }} \times 100 \%$ $=\frac{\text { Rp. } 9.565 .000}{\text { Rp. } 125.327 .500} \times 100 \%$

$=0.07632$

$=7.632 \%$

Artinya setiap Rp 1 hutang dijamin oleh Rp 0,076 aktiva (harta perusahaan).

\section{2). Debt to Equity Ratio}

Debt to Equity Ratio

$=\frac{\text { Total Hutang }}{\text { Total Modal }} \times 100 \%$

$=\frac{\text { Rp. } 9 \cdot 565 \cdot 000}{\text { Rp. } 115 \cdot 762 \cdot 500} \times 100 \%$

$=0.08262$

$=8.262 \%$

Artinya setiap $\mathrm{Rp} 1$ hutang dijamin oleh $\mathrm{Rp} 0,082$ modal sendiri.

\section{Kesimpulan}

Berdasarkan pembahasan diatas, maka kesimpulannya adalah sebagai berikut:

1. Sistem yang telah terkomputerisasi dapat mempermudah pengolahan data dan penyusunan laporan keuangan dengan waktu yang relatif singkat dan hasil yang akurat.

2. MYOB Premier V16 merupakan program aplikasi akuntansi yang digunakan untuk pengolahan data transaksi yang mampu menampilkan laporan keuangan secara lengkap, cepat dan akurat. Dalam penggunaan aplikasi ini bisa mengefisien waktu. Selain itu aplikasi ini juga memiliki tingkat keamanan yang cukup vaild dibanding kan dengan sistem manual.

3. Dalam hal penyimpanan data dalam komputer lebih aman dan lebih cepat dalam pencariannya.

Penggunaan aplikasi Sofware Accounting MYOB Premier V16 sangat diperlukan ketelitian dan kedisiplinan dari user, terutama pada saat penginputan transaksi agar menghasilkan output sesuai 
dengan kebutuhan. Perusahaan mengadakan program pelatihan terlebih dahulu kepada karyawan pengguna aplikasi akuntansi sehingga dapat menguasi aplikasi dengan baik.

\section{Referensi}

Astuty, T. (2015). Rangkuman Inti Sari Ekonomi Lengkap SMA Kelas 1, 2, 3. Jakarta: Vicosta Publishing.

Eddy, R. (2010). Aspek Legal PropertiTeori, Contoh, dan Aplikasi.

Krismiaji. (2015). Sistem Informasi Akuntansi. Yogyakarta: UPP STIM YKPN.

Normah. (2018). Implementasi It Pada Sistem Informasi Akuntansi Pt. Master Grafika Jakarta. Jurnal Teknik Komputer, 4(1), 56-65. Retrieved from

http://ejournal.bsi.ac.id/ejurnal/index.p $\mathrm{hp} / \mathrm{jtk} /$ article/view/2442/1905

Rahmawati, M. (2015). Usaha Dalam Persfektif Sistem Informasi. Perspekti, $X I I I(2)$, 173. Retrieved from http://ejournal.bsi.ac.id/ejurnal/index.p $\mathrm{hp} /$ perspektif/article/view/921

Rosa; Shalahuddin. (2011). Rekayasa Perangkat Kunak (Terstruktur dan Berorientasi Objek).

Shatu, Y. P. (2016). Kuasai Detail Akuntansi Laba dan Rugi. https://doi.org/Yogyakarta: Pustaka Ilmu Semesta

Zamzami, F., Nusa, N. D., \& Faiz, I. A. (2016). Sistem Informasi Akuntansi: Penggunaan Teknologi Informasi untuk meningkatkan kualitas. Yogyakarta: Gadjah Mada University Press. 